\title{
《环境科学研究》2018 年度优秀论文评选结果
}

为了进一步促进学术交流, 鼓励广大环保科研工作者不断创新, 积极将科技成果写在祖国的大地上, 《环 境科学研究》开展了 2018 年度优秀论文评选工作, 现将评选结果予以发布, 非常感谢广大专家、学者对本刊的 关心、支持和帮助,期待得到大家的持续关注!

优秀论文评选办法:2018 年度期刊发表论文 259 篇, 以中国知网检索数据库提供的文献被引频次为依据, 最终确定 25 篇论文为 2018 年度优秀论文。具体评选结果如下:

\begin{tabular}{|c|c|c|c|}
\hline 序号 & 文题 & 作者 & 期数 \\
\hline 1 & $\begin{array}{l}\text { 中国作物秸秆资源利用潜力的多适宜性综合 } \\
\text { 评价 }\end{array}$ & 曹志宏, 黄艳丽, 郝晋珢 & 1 \\
\hline 2 & $\begin{array}{l}\text { 长江流域总磷污染: 分布特征·来源解析·控 } \\
\text { 制对策 }\end{array}$ & $\begin{array}{l}\text { 秦延文, 马迎群, 王丽婧, 郑丙辉 *, 任春坪, } \\
\text { 佟洪金, 王鹤扬 }\end{array}$ & 1 \\
\hline 3 & $\begin{array}{l}\text { 三峡工程运行对洞庭湖水环境及富营养化风 } \\
\text { 险影响评述 }\end{array}$ & $\begin{array}{l}\text { 王 婷, 王 坤, 王丽婧, 田泽斌, 黄 威, } \\
\text { 姜 霞* }\end{array}$ & 1 \\
\hline 4 & $\begin{array}{l}\text { 青岛冬季 } \mathrm{PM}_{2.5} \text { 持续重污染天气的大气边界 } \\
\text { 层特征 }\end{array}$ & 马 艳, 黄 容, 时晓曚, 王建林, 孙 萌 & 1 \\
\hline 5 & $\begin{array}{l}\text { 基于高通量测序检测 } \mathrm{Pb} \text { 污染对三叶草根际 } \\
\text { 土壤细菌多样性的影响 }\end{array}$ & 王继玥, 刘 燕*, 刘 勇, 石登红 & 1 \\
\hline 6 & 西洞庭湖人湖河流磷的污染特征 & $\begin{array}{l}\text { 蔡 佳, 王丽婧*, 陈建湘, 田泽斌, 汪 星, } \\
\text { 黄代中, 刘德富* }\end{array}$ & 1 \\
\hline 7 & $\begin{array}{l}\mathrm{Fe}_{3} \mathrm{O}_{4} / \mathrm{BC} \text { 复合材料的制备及其吸附除磷 } \\
\text { 性能 }\end{array}$ & 胡小莲, 杨林章, 何世颖 " , 冯彦房, 周玉玲 & 1 \\
\hline 8 & $\begin{array}{l}\text { 基于 Model-3/CMAQ 模式的本溪市大气细颗 } \\
\text { 粒物数值模拟 }\end{array}$ & 秦思达, 惠秀娟 *, 夏广锋, 王淑兰 & 1 \\
\hline 9 & $\begin{array}{l}\text { 过硫酸钠对我国典型土壤中多环芳烃氧化降 } \\
\text { 解效果的影响 }\end{array}$ & $\begin{array}{l}\text { 邸莎, 张超艳, 颜增光, 白利平, 周友亚 }{ }^{*} \text {, } \\
\text { 王学东 }{ }^{*} \text {, 李发生 }\end{array}$ & 1 \\
\hline 10 & 气候变化对浙江省大气污染的影响 & 毛敏娟, 杜荣光, 胡德云 & 2 \\
\hline 11 & $\begin{array}{l}\text { 微生物诱导碳酸盐沉淀及其在固定重金属领 } \\
\text { 域的应用进展 }\end{array}$ & 王茂林, 吴世军 ${ }^{*}$, 杨永强, 陈繁荣 & 2 \\
\hline
\end{tabular}


续表

\begin{tabular}{|c|c|c|c|}
\hline 序号 & 文题 & 作者 & 期数 \\
\hline 12 & 好氧颗粒污泥技术处理乡镇污水应用 & $\begin{array}{l}\text { 姚 源, 竺建㭉, 唐 敏, 陈刚才, 黄健盛*, } \\
\text { 陈婷婷, 廖伟伶 }\end{array}$ & 2 \\
\hline 13 & $\begin{array}{l}\text { 滦河流域鱼类群落结构空间异质性与影响因 } \\
\text { 子分析 }\end{array}$ & $\begin{array}{l}\text { 王晓宁, 彭世贤, 张 亚, 张 远, 钱 永, } \\
\text { 丁 森* }\end{array}$ & 2 \\
\hline 14 & $\begin{array}{l}\text { 增强环保科技创新能力 支撑环境管理决策: } \\
\text { 需求·挑战·对策 }\end{array}$ & 李海生 & 2 \\
\hline 15 & 常州市冬季大气污染特征及潜在源区分析 & 何 涛, 彭 燕, 乔利平, 滕加泉, 薛银刚 & 3 \\
\hline 16 & $\begin{array}{l}\text { 永定河底栖动物生物完整性指数构建与健康 } \\
\text { 评价 }\end{array}$ & $\begin{array}{l}\text { 慕林青, 张海萍, 赵树旗, 刘培斌, 高晓薇, } \\
\text { 李玉臣, 渠晓东 * }\end{array}$ & 4 \\
\hline 17 & $\begin{array}{l}\text { 阿什河流域 } 10 \text { 种水生植物对水质氮磷的净 } \\
\text { 化能力比较 }\end{array}$ & $\begin{array}{l}\text { 杨 帆, 刘赢男, 焉志远, 隋 心, 袁 否, } \\
\text { 倪红伟* }\end{array}$ & 4 \\
\hline 18 & 环境规制对碳排放的门槛效应及其区域差异 & 王雅楠, 左艺辉, 陈 伟*, 王博文 & 4 \\
\hline 19 & $\begin{array}{l}\text { 石家庄市采暖前后大气颗粒物及其碳组分 } \\
\text { 特征 }\end{array}$ & $\begin{array}{l}\text { 李 璇, 赵晓楠, 俞 磊, 肖捷颖, 王建国, } \\
\text { 段二红* }\end{array}$ & 4 \\
\hline 20 & 安徽省大气污染物时空分布特征及演化规律 & 王化杰, 张 波, 胡 昊, 张永江 & 4 \\
\hline 21 & 危险废物环境风险防控关键问题与对策 & 黄启飞,王＼cjkstart菲,黄泽春,杨玉飞,李 & 5 \\
\hline 22 & $\begin{array}{l}\text { 肥料对土壤重金属有效态及水稻幼苗重金属 } \\
\text { 积累的影响 }\end{array}$ & $\begin{array}{l}\text { 何其辉, 谭长银 *, 曹雪莹, 梁玉峰, 代 兵, } \\
\text { 朱上游, 谢雨呈 }\end{array}$ & 5 \\
\hline 23 & $\begin{array}{l}\text { 页岩气开发地下水污染风险评价指标体系 } \\
\text { 构建 }\end{array}$ & $\begin{array}{l}\text { 李绍康, 袁 颖*, 李 翔*, 刘可欣, 杨津津, } \\
\text { 余 红 }\end{array}$ & 5 \\
\hline 24 & $\begin{array}{l}\text { “绿水青山就是金山银山” 理论实践政策机 } \\
\text { 制研究 }\end{array}$ & 秦昌波, 苏洁琼 ${ }^{*}$,王 倩, 万 军, 王金南 & 6 \\
\hline 25 & $\begin{array}{l}\text { 聊城市冬季 } \mathrm{PM}_{2.5} \text { 及水溶性离子污染特征及 } \\
\text { 来源分析 }\end{array}$ & $\begin{array}{l}\text { 张敬巧, 王淑兰 *, 罗达通, 陈振兴, 王 涵, } \\
\text { 张 萌, 胡 君 }\end{array}$ & 10 \\
\hline
\end{tabular}

注:优秀论文按发表时间排序; * 为责任作者.

《环境科学研究》编辑部 2020 年 1 月 